\title{
Study of Evaluation of Pollination Efficiency of Major Insect Pollinators on Summer Squash (Cucurbita pepo L.)
}

\author{
D. Devika Rani*, H.D. Kaushik, G. Narendra kumar and B. Triveni \\ Department of Entomology, UAS, GKVK, Bengaluru, India \\ *Corresponding author
}

\section{A B S T R A C T}

\begin{tabular}{|l|}
\hline Ke y w o r d s \\
Pollination \\
efficiency, Hybrids, \\
Pollination, \\
Summer squash, \\
Forager \\
\hline Article Info \\
\hline Accepted: \\
04 August 2019 \\
Available Online: \\
10 September 2019 \\
\hline
\end{tabular}

\section{Introduction}

Pollination plays an important role in the reproduction and fruit set of flowering plants (Buchmann and Nabhan, 1996). Animal pollinators are thought to contribute $15-30 \%$ of the global food production (Roubik, 1995). Summer squash is an upright non-trailing bush (in contrast to climbing growth habit of most cucurbits) with $45-75 \mathrm{~cm}$ height. Fruits come in diverse forms from oblong or elongate to flatten but some varieties have a crook-necked fruits. The fruit surface may be smooth, scalloped, ridged, or warty and colour may

\begin{abstract}
An experiment on the insect pollinators was conducted with four summer squash hybrids viz., Parikrama, Chandra, Chamatkar and Gold Queen at the Research Farm of the Department of Entomology, CCS Haryana Agricultural University, Hisar. Based on pollination index (loose pollen grains sticking on the body $\mathrm{x}$ abundance $\mathrm{x}$ foraging rate), $A$. mellifera was the most efficient pollinator of $C$. pepo with pollination index of 1177360 followed by A. dorsata (773280) and A. cerana (223420) and A. florea with pollination index 63480 under agro-ecological conditions of Hisar (Haryana). The abundance bees $/ \mathrm{m} 2 / 5$ minutes) of A. mellifera (2.21) was highest followed by A. cerana (1.16), A. rsata (1.07) and A. florea (0.62). Irrespective of species, the population was maximum ( $45 \mathrm{bees} / \mathrm{m} 2 / 5$ minutes) at $1000-1200 \mathrm{~h}$ of the day. Foragers of A. dorsata, A. mellifera, . florea and A. cerana commenced their pollen collection activity at 0600, 0630, 0700 and $0700 \mathrm{~h}$, with peak periods at 0600-0800, 0800-1000, 1000-1200 and 0800-1000 h respectively and all of them ceased their activity between $1700-1800 \mathrm{~h}$.
\end{abstract}

vary from white or cream to yellow to green but some are variegated or striped. Its fruits develop rapidly after flowering, and thus, they are harvested within few days before the seeds and rind become hard and the flesh becomes fibrous. The plant bears male and female flowers separately on same branch with many more male flowers usually being present. Bees are the most versatile, active and best-known pollinators. Pollination efficiency of different insect pollinators has been evaluated based on number of characteristics. Most of the workers (Atwal, 1970) considered the relative effectiveness of various species to affect 
pollination in spite of their abundance (Free et al., 1975; Anderson et al., 1982). Therefore, the efficiency of an insect species as a pollinator has also been attributed to its size, foraging behaviour and the amount of loose pollen grains adhering to its body (Bohart and Nye, 1960; Free et al., 1975). Brantjes and Leemans (1976) noticed that the large sized insects were effective in pollination of flowers due to their body contact with anthers and stigmas as compared to small sized insects, which often missed their contact with anthers and stigmas while foraging for floral rewards.

In addition, bees are faithful to one species of flower per trip (floral constancy), which greatly facilitates pollination. Various workers (Atwal, 1970; Kapil and Brar, 1971; Free, 1993) considered the relative effectiveness of insect pollinators of crops based on their abundance alone. Baker et al., (1971) reported that the frequency of flower visitors, the number of flowers visited per unit time and the amount of pollen grains picked per visit helped to distinguish the pollinators as major and minor ones, however, he admitted that there were inherent differences in the ability of various species to affect pollination in spite of their abundance (Anderson et al., 1982). Therefore, efficiency of an insect as a pollinator has also been attributed to its size, foraging behaviour, and the amount of loose pollen grains adhering to its body (Free et al., 1975).

There are many native bee species in India. Hence, it is essential to estimate the contribution of pollinators in pollinating the summer squash flowers. Keeping this idea in view, the present investigation was carried out with the objective of studying the impact of insect pollinators and pollination methods on yield parameters, viz. Percent fruit set, fruit length, fruit diameter and fruit weight of summer squash. Lot of work had been done in India and abroad on its agronomic practices, medicinal uses, distribution, pollen viability and pistil receptivity (Nepi and Pacini, 1993) but little research has been addressed in India on the role of insect pollinators on fruit production and efficiency of different insect pollinators on pollination of summer squash. Philippe (1991) reported occasional visit by Diptera, Lepidoptera and Coleoptera. Other insects found on the flowers included Halictids (Pseudougochloropsis sp.) and Xylocopids (Xylocopa sp.) as nectar gatherers (Couto et al., 1990). Based on pollination index (loose pollen grains sticking on the body $\mathrm{x}$ abundance $\mathrm{x}$ foraging rate) pollination efficiency was calculated.

\section{Materials and Methods}

The summer squash crop was raised at Research Farm of the Department of Entomology , CCS Haryana Agricultural University, Hisar. The field area $(48 \times 16 \mathrm{~m})$ was first divided into 4 equal plots of $8 \mathrm{~m}$ width and $24 \mathrm{~m}$ length with irrigation channels of $50 \mathrm{~cm}$ width and $20 \mathrm{~cm}$ depth. Four hybrids viz., Parikrama, Chandra, Chamatkar and Gold Queen were sown, before sowing treated with Captan @ $3 \mathrm{~g} / \mathrm{kg}$. Per hill, two seeds were sown on single side edge of the raised bed keeping a distance of $80 \mathrm{~cm}$ between rows and $50 \mathrm{~cm}$ between plants.

For abundance by using a cone type hand net, the insects visiting the flowers of summer squash were collected by sweep method, and sweeps were made through out flowering period at different hours of the day. The collected insects were preserved as dry specimen and were identified. Counts of insect visitors were made on flowers of Cucurbita pepo per square metre for 5 minutes using a hand tally counter between different day hours following the methods given by Free (1993). The observations were started when 10per cent of the plants came into bloom. 


\section{Foraging rate}

The foraging rate of different types of insect visitors was recorded in terms of the number of flowers visited per minute.

\section{Loose pollen grains sticking on the body of insect pollinators}

For estimating the number of loose pollen grains sticking to the body of different insect

\section{Results and Discussion}

\section{Abundance}

Data on abundance of different bee species on summer squash flowers at different hours of the day have been presented in Table 1. Variations in abundance were recorded over time and space. No bee population was observed during 1200-1600 h. The mean number of bee species over different day hours on summer squash flowers ranged from 0.62 (A. florea) to 2.21 bees $/ \mathrm{m} 2 / 5$ minutes $(A$. mellifera). Irrespective of species, the abundance of bees was lowest at 1600-1800 h (1.10 bees/m2/5 minutes) and highest at 1000$1200 \mathrm{~h}$ (1.45 bees $/ \mathrm{m} 2 / 5$ minutes). The cumulative mean abundance of important bee species revealed that $A$. mellifera was the most abundant visitor with a mean population of 2.21 bees $/ \mathrm{m} 2 / 5$ minutes followed by $A$. cerana (1.16 bees $/ \mathrm{m} 2 / 5$ minutes), A. dorsata (1.07 bees $/ \mathrm{m} 2 / 5$ minutes) and $A$. florea was as least frequent $(0.78$ bees $/ \mathrm{m} 2 / 5$ minutes $)$ visitor of summer squash flowers in the present investigations (Table 1).

All the bee species started visiting the crop from $0600 \mathrm{~h}$ of the day but their abundance varied during different intervals of the day. $A$. dorsata and $A$. mellifera were most abundant during 1000 to $1200 \mathrm{~h}$ of the day (1.63 and 2.50 bees $/ \mathrm{m} 2 / 5$ minutes, respectively) while $A$. florea was most abundant during 0600 to 0800 h ( 0.83 bees $/ \mathrm{m} 2 / 5$ minutes $)$ and $A$. cerana during 1600 to $1800 \mathrm{~h}(1.46 \mathrm{bees} / \mathrm{m} 2 / 5$ minutes) of the day (Table 1 ).

Data on abundance of different bee species on summer squash flowers at different hours of the day have been presented in Table 1. Variations in abundance were recorded over time and space. No bee population was observed during 1200-1600 h. The mean number of bee species over different day hours on summer squash flowers ranged from 0.62 (A. florea) to 2.21 bees $/ \mathrm{m} 2 / 5$ minutes $(A$. mellifera). Irrespective of species, the abundance of bees was lowest at 1600-1800 h (1.10 bees $/ \mathrm{m} 2 / 5$ minutes) and highest at 1000 $1200 \mathrm{~h}$ (1.45 bees $/ \mathrm{m} 2 / 5$ minutes). The cumulative mean abundance of important bee species revealed that $A$. mellifera was the most abundant visitor with a mean population of $2.21 \mathrm{bees} / \mathrm{m} 2 / 5$ minutes followed by A. cerana (1.16 bees $/ \mathrm{m} 2 / 5$ minutes), A. dorsata (1.07 bees $/ \mathrm{m} 2 / 5$ minutes) and $A$. florea was least frequent $(0.78$ bees $/ \mathrm{m} 2 / 5$ minutes $)$ visitor of summer squash flowers in the present investigations.

All the bee species started visiting the crop from $0600 \mathrm{~h}$ of the day but their abundance varied during different intervals of the day. $A$. dorsata and $A$. mellifera were most abundant during 1000 to $1200 \mathrm{~h}$ of the day (1.63 and 2.50 bees $/ \mathrm{m} 2 / 5$ minutes, respectively) while $A$. florea was most abundant during 0600 to 0800 $\mathrm{h}(0.83$ bees $/ \mathrm{m} 2 / 5$ minutes $)$ and $A$. cerana during 1600 to $1800 \mathrm{~h}(1.46$ bees $/ \mathrm{m} 2 / 5$ minutes) of the day.

\section{Foraging rate}

The data on number of flowers visited per minute (foraging rate) by different bee species on summer squash flowers have been presented in Table 2. The number of flowers visited by four bee species differed significantly during different times of the day. 
The mean foraging rate in case of A. mellifera varied from 5.20 to 6.07 flowers during different hours of the day. It was 3.13 to 3.33 flowers in case of A. cerana, 3.90 to 5.26 flowers in case of $A$. dorsata and 1.97-2.20 flowers for A. florea. Among the bee species, the mean foraging rate was highest in $A$. mellifera (5.45 flowers/minute), followed by A. dorsata (4.38 flowers/minute) and $A$. cerana (3.21 flowers/minute), and it was lowest in A. florea (2.10 flowers/minute).

\section{Number of loose pollen grains sticking to} the body of a bee

The number of loose pollen grains sticking to the body of bees while foraging on summer squash flowers has been presented in Table 3. Significant differences were found among the number of loose pollen grains sticking to the body of different foragers. A. dorsata had the highest loose pollen grains on their body (165000 pollen grains) followed by $A$. mellifera ( 97750 pollen grains) and A. cerana (60,000 pollen grains), and it was lowest in case of A. florea (48750 pollen grains). Irrespective of four bee species, the number of loose pollen grains sticking to the body of bee did not differ significantly among different hybrids of summer squash. It was highest in cultivar Chamatkar (94500 pollen grains), followed by Chandra (93750 pollen grains), Parikrama (92500 pollen grains) and lowest in Gold Queen (90750 pollen grains) hybrid.

\section{Pollination efficiency}

The data on pollination efficiency of different bee species foraging on summer squash flowers presented in Table 4. depict that $A$. mellifera entrapped the maximum number of pollen grains (165000 pollen grains) followed by $A$. dorsata (97750 pollen grains), A. cerana (60000 pollen grains) and A. florea (av. 48750 pollen grains).

Table.1 Abundance of different bee species on flowers of Cucurbita pepo during different hours of the day

\begin{tabular}{|l|l|l|l|l|l|}
\hline \multirow{2}{*}{ Bee species } & \multicolumn{6}{|l|}{ Number of bees/m2/5 minutes during different day hours } \\
\cline { 2 - 6 } & $\mathbf{0 6 0 0 - 0 8 0 0}$ & $\mathbf{0 8 0 0 - 1 0 0 0}$ & $\mathbf{1 0 0 0 - 1 2 0 0}$ & $\mathbf{1 6 0 0 - 1 8 0 0}$ & Mean \\
\hline Apis dorsata & $0.66(1.28)$ & $1.33(1.53)$ & $1.63(1.67)$ & $0.66(1.28)$ & $\mathbf{1 . 0 7}(\mathbf{1 . 4 4 )}$ \\
\hline Apis mellifera & $2.17(1.76)$ & $2.33(1.82)$ & $2.5(1.87)$ & $1.83(1.66)$ & $\mathbf{2 . 2 1}(\mathbf{1 . 7 8})$ \\
\hline Apis florea & $0.83(1.29)$ & $0.67(1.35)$ & $0.51(1.29)$ & $0.46(1.23)$ & $\mathbf{0 . 6 2}(\mathbf{1 . 2 9})$ \\
\hline Apis cerana & $1.16(1.52)$ & $0.83(1.47)$ & $1.17(1.34)$ & $1.46(1.53)$ & $\mathbf{1 . 1 6}(\mathbf{1 . 4 7})$ \\
\hline Mean & $\mathbf{1 . 2 1}(\mathbf{1 . 4 6})$ & $\mathbf{1 . 2 9}(\mathbf{1 . 5 4})$ & $\mathbf{1 . 4 5}(\mathbf{1 . 5 5})$ & $\mathbf{1 . 1 0}(\mathbf{1 . 4 2})$ & \\
\hline
\end{tabular}

Each value represents mean of 20 observations

Figures in parenthesis are transformed values.

\begin{tabular}{|l|r|r|}
\hline & SE(m) & C.D. $(\boldsymbol{p = 0 . 0 5})$ \\
\hline Bee species & $(0.04)$ & $(0.13)$ \\
\hline Day hours & $(0.04)$ & $(0.15)$ \\
\hline Bee species $\times$ Day hours & $(0.08)$ & $(0.27)$ \\
\hline
\end{tabular}


Table.2 Foraging rate of different bee species on flowers of Cucurbita pepo during different hours of the day

\begin{tabular}{|l|l|l|l|l|l|l|}
\hline \multirow{2}{*}{ Bee species } & \multicolumn{7}{|c|}{ Number of flowers visited per minute } \\
\cline { 2 - 7 } & $\mathbf{0 6 0 0 - 0 8 0 0}$ & $\mathbf{0 8 0 0 - 1 0 0 0}$ & $\mathbf{1 0 0 0 - 1 2 0 0}$ & $\mathbf{1 6 0 0 - 1 8 0 0}$ & Mean \\
\hline Apis dorsata & $4.27(2.31)$ & 5.26 & $(2.24)$ & $4.10(2.20)$ & $3.90(2.27)$ & $\mathbf{4 . 3 8}(\mathbf{2 . 2 6})$ \\
\hline Apis mellifera & $5.21(2.21)$ & 6.07 & $(2.23)$ & $5.31(2.48)$ & $5.20(2.47)$ & $\mathbf{5 . 4 5}(\mathbf{2 . 3 5})$ \\
\hline Apis florea & $2.20(1.42)$ & 2.07 & $(1.48)$ & $2.17(1.45)$ & $1.97(1.48)$ & $\mathbf{2 . 1 0}(\mathbf{1 . 4 6 )}$ \\
\hline Apis cerana & $3.20(2.47)$ & 3.33 & $(2.51)$ & $3.13(2.50)$ & $3.17(2.45)$ & $\mathbf{3 . 2 1}(\mathbf{2 . 4 9})$ \\
\hline Mean & $\mathbf{3 . 7 2}(\mathbf{2 . 1 0})$ & $\mathbf{4 . 1 8}$ & $\mathbf{( 2 . 1 1 )}$ & $\mathbf{3 . 6 8}(\mathbf{2 . 1 6})$ & $\mathbf{3 . 5 6}(\mathbf{2 . 1 8})$ & \\
\hline
\end{tabular}

Each value represents 20 observations

Figures in the parentheses are $\sqrt{ }(\mathrm{x}+1)$ transformed values

Table.3 Per cent abundance of different bee species on flowers of Cucurbita pepo during different hours of the day

\begin{tabular}{|l|c|c|c|c|c|}
\hline \multirow{2}{*}{ Bee species } & \multicolumn{5}{|c|}{ Number of bees/m2/5 minutes during different day hours } \\
\cline { 2 - 6 } & $\mathbf{0 6 0 0 - 0 8 0 0}$ & $\mathbf{0 8 0 0 - 1 0 0 0}$ & $\mathbf{1 0 0 0 - 1 2 0 0}$ & $\mathbf{1 6 0 0 - 1 8 0 0}$ & Mean \\
\hline Apis dorsata & $15.42(0.66)$ & $31.07(1.33)$ & $38.08(1.63)$ & $15.42(0.66)$ & $\mathbf{2 1 . 1 9}(\mathbf{4 . 2 8})$ \\
\hline Apis mellifera & $24.58(2.17)$ & $26.39(2.33)$ & $28.31(2.50)$ & $20.72(1.83)$ & $\mathbf{4 3 . 7 1}(\mathbf{8 . 8 3})$ \\
\hline Apis florea & $33.60(0.83)$ & $27.13(0.67)$ & $20.65(0.51)$ & $18.62(0.46)$ & $\mathbf{1 2 . 2 3}(\mathbf{2 . 4 7})$ \\
\hline Apis cerana & $25.11(1.16)$ & $17.97(0.83)$ & $25.32(1.17)$ & $31.60(1.46)$ & $\mathbf{2 2 . 8 7 ( 4 . 6 2 )}$ \\
\hline Mean & $\mathbf{2 3 . 8 6}(\mathbf{1 . 2 1})$ & $\mathbf{2 5 . 5 4}(\mathbf{1 . 2 9})$ & $\mathbf{2 8 . 7 6 ( 1 . 4 5 )}$ & $\mathbf{2 1 . 8 3 ( 1 . 1 0 )}$ & \\
\hline
\end{tabular}

Each value represents mean of 20 observations

Table.4 Pollination efficiency of different bee species on flowers of Cucurbita pepo

\begin{tabular}{|c|l|l|l|l|l|}
\hline Bee species & $\begin{array}{l}\text { Abundance } \\
\text { (bees/m2/5 } \\
\text { minutes) }\end{array}$ & $\begin{array}{l}\text { Number of loose } \\
\text { pollen grains } \\
\text { sticking on the } \\
\text { body of a bee }\end{array}$ & $\begin{array}{l}\text { Foraging } \\
\text { rate }\end{array}$ & $\begin{array}{l}\text { Pollination index } \\
\text { (abundance } \times \text { loose } \\
\text { pollen grains x } \\
\text { foraging rate) }\end{array}$ & $\begin{array}{l}\text { Pollination } \\
\text { efficiency } \\
\text { (Rank) }\end{array}$ \\
\hline Apis dorsata & 1.07 & 165.00 & 4.38 & 773.28 & 2nd \\
\hline Apis mellifera & 2.21 & 97.75 & 5.45 & 1177.36 & 1st \\
\hline Apis florea & 0.62 & 48.75 & 2.10 & 63.48 & 4th \\
\hline Apis cerana & 1.16 & 60.00 & 3.21 & 223.42 & 3rd \\
\hline
\end{tabular}

The abundance of $A$. mellifera $(2.21$ bees/m2/5 minutes) was highest followed by A. cerana (1.16 bees/m2/5 minutes) and $A$. dorsata (1.07 bees $/ \mathrm{m} 2 / 5$ minutes), while the abundance of $A$. florea was least (0.62 bees $/ \mathrm{m} 2 / 5$ minutes) and the foraging rate of A. mellifera (5.45 flowers visited/minutes) was highest followed by $A$. cerana (3.21 flowers visited/minutes) and $A$. dorsata (4.38 flowers visited/minutes), while the foraging rate of $A$. florea was least (2.10 flowers visited/minutes) but the pollination index of A. mellifera was highest (1177360) followed by A. dorsata (773280), A. cerana (223420) and A. florea (63480). Hence, it was observed that $A$. mellifera was the most efficient pollinator followed by A. dorsata, A. cerana and $A$. florea on summer squash flowers under agro-ecological conditions of Hisar. 
The data on foraging activity of different bee species on summer squash flowers presented in Table 4 depict that $A$. dorsata initiated foraging activity on summer squash flowers little earlier in the morning and ceased its activity little later in the evening when compared to A. mellifera, A. cerana and $A$. florea. A. dorsata started collecting pollens from $0600 \mathrm{~h}$ of the day, A. mellifera from $0630 \mathrm{~h}$ while $A$. cerana and A. florea from $0700 \mathrm{~h}$ of the day. Peak activity in pollen collection was observed during 0600-0800 h (A. dorsata), 0800-1000 h (A. mellifera and A. cerana) and 1000-1200 h (A. florea) of the day. Foraging activity for nectar by $A$. dorsata initiated from $0630 \mathrm{~h}$ of the day while in $A$. mellifera and A. cerana it started from $0730 \mathrm{~h}$ and in A. florae from $0800 \mathrm{~h}$ of the day. However, all the four bee species attained their peak nectar foraging activity during 1000-1200 h of the day.

It is concluded based on pollination index (loose pollen grains sticking on the body $\mathrm{x}$ abundance $\mathrm{x}$ foraging rate), A. mellifera was the most efficient pollinator of $C$. pepo with pollination index of 1177360 followed by $A$. dorsata (773280) and A. cerana (223420) and A. florea with pollination index 63480 under agro-ecological conditions of Hisar (Haryana). The abundance (bees $/ \mathrm{m} 2 / 5$ minutes) of $A$. mellifera (2.21) was highest followed by $A$. cerana (1.16), A. dorsata (1.07) and $A$. florea (0.62). Irrespective of species, the population was maximum (1.45 bees $/ \mathrm{m} 2 / 5$ minutes) at $1000-1200 \mathrm{~h}$ of the day. Foragers of A. dorsata, A. mellifera, A. florea and $A$. cerana commenced their pollen collection activity at 0600, 0630, 0700 and $0700 \mathrm{~h}$, with peak periods at 0600-0800, 0800-1000, 1000-1200 and 0800-1000 h respectively and all of them ceased their activity between $1700-1800 \mathrm{~h}$. Out of the total foragers of the day for A. mellifera, 47.93 per cent were pollen, 19.01per cent were nectar collectors and 33.06 per cent were pollen+nectar collectors. A. mellifera spent maximum time (10.30 seconds/flower), whereas, A. florea spent least time (2.51 seconds/flower) while these values are 7.61 and 5.10 seconds/flower for $A$. dorsata and $A$. cerana. Based on pollination index (loose pollen grains sticking on the body $\mathrm{x}$ abundance $\mathrm{x}$ foraging rate), A. mellifera was the most efficient pollinator of $C$. pepo with pollination index of 1177360 followed by $A$. dorsata (773280) and A. cerana (223420) and $A$. florea with pollination index 63480 under agro-ecological conditions of Hisar (Haryana).

\section{References}

Anderson, D.L., Sedgeley, M., Short, J.R.T. and Allwood, A.J., 1982. Insect pollination of mango in northern Australia. Australian J. agric. Res., 33: 541-548.

Atwal, A.S., 1970. Insect pollinators of crops (biology, ecology and utilization of insects other honey bees in the pollination of crops. Final Research Report 1968-70 of Punjab Agricultural University, Ludhiana, Punjab, India, $116 \mathrm{p}$.

Baker, H.G., Cruden, R.W. and Baker, I., 1971. Minor parasitism in pollination biology and its community function: the case of Ceiba acuminate. Bio. Sci., 21: 1127-1129.

Bohart, G.E. and Nye, W.P., 1960. Insect pollinators of carrot in Utah. Bull. Utah agric. Expt. Stn., 419: 1-6.

Brantjes, N.B.M. and Leemans, J.A.A.M., 1976. Silane otites (Carryophyllaceae) pollinated by nocturnal Lepidoptera and mosquitoes. Acta Botanica Neerlandica, 25: 281-285.

Buchmann, L.S. and Nabhan, P.G., 1996. The Forgotten Pollinators, Island Press, Washington DC, USA, $292 \mathrm{p}$.

Free, J.B., Williams, I.H., Longden, P.C. and 
Johnson, M.G., 1975. Insect pollination of sugar beet (Beta vulgaris L.) seed crops. Ann. Appl. Biol., 81: 127-134.

Roubik, D.W., 1995. Pollination of cultivated plants in the Tropics. FAO Agric. Serv. Bull. 18, Rome, Italy, $118 \mathrm{p}$.
Nepi, M. and Pacini, E., 1993. Pollination, pollination viability and pistil receptivity in Cucurbita pepo. Ann. Bot., 72: 527-536.

Philippe, J.M., 1991. La Pollination Par Les Abeilles. Aix-en-province; Edisud.

\section{How to cite this article:}

Devika Rani, D., H.D. Kaushik, G. Narendra Kumar and Triveni, B. 2019. Study of Evaluation of Pollination Efficiency of Major Insect Pollinators on Summer Squash (Cucurbita pepo L.). Int.J.Curr.Microbiol.App.Sci. 8(09): 178-184. doi: https://doi.org/10.20546/ijcmas.2019.809.023 